\title{
DISPERSION DISTORTION TRACKING COMPENSATOR BASED ON THE SIGMA-POINT KALMAN
}

Evgeniy M. Lobov,

Moscow Technical University of Communications and Informatics, Moscow, Russia, lobov@srd.mtuci.ru

\section{Vladimir S. Priputin,}

Moscow Technical University of Communications and Informatics, Moscow, Russia, v.s.priputin@mtuci.ru

\section{Elizaveta O. Lobova,}

Moscow Technical University of Communications and Informatics, Moscow, Russia, lizabeth2@mail.ru

Efim A. Liberman,

Moscow Technical University of Communications and Informatics, Moscow, Russia
DOI: $|0.36724 / 2072-8735-202|-|5-|-4 \mid-47$

Manuscript received 18 October 2020; Accepted 20 December 2020

Keywords: frequency dispersion, broadband signal, distortions, nonlinear optimal filtering, Kalman sigma-point filter, ARM

The article proposes an algorithm for nonlinear optimal filtering of the dispersion characteristic slope of the ionospheric channel (DC slope) based on the Kalman sigma-point filter when sounding the channel with broadband signals. The relevance of the applied algorithm can be explained by the fact that at present in the modern world the relevance of the transmission of broadband information signals in the decameter range has increased. The reception of such signals is complicated by the effects caused by the influence of the frequency dispersion of the ionospheric channel on the signal. The above influence leads to significant distortions of the useful signal and a decrease in the quality of information reception in general. The above influence leads to significant distortions of the useful signal and a decrease in the quality of information reception in general. Therefore, the effect of frequency dispersion cannot be neglected and must be taken into account when developing algorithms for optimal reception. Thus, estimation of the parameters of the frequency dispersion of the ionospheric channel becomes an urgent task. The article provides recurrent formulas for calculating the optimal filtration of the DC slope. Moreover, an algorithm for joint estimation of dispersion distortions and their compensation is presented, which allows improving the quality of estimation. The results of simulation modeling of the algorithms are given: the obtained estimate and the true value of the frequency dispersion parameters for two cases - a Markov damped process and a process with random increments. The absolute error in estimating the DC slope is also considered. The computational efficiency of the algorithm for estimating the DC slope using the Kalman sigma-point filter with and without compensation is calculated. In addition, functional diagrams of optimal filtering of the DC slope with compensation and without compensation are given. The ways of implementing the proposed algorithm on an ARM processor are considered.

Information about authors:

Evgeniy M. Lobov, Head of a Laboratory, Candidate of Technical Sciences, Docent, Moscow Technical University of Communications and Informatics, Moscow, Russia

Vladimir S. Priputin, Head of a Laboratory, Candidate of Technical Sciences, Docent, Moscow Technical University of Communications and Informatics, Moscow, Russia

Elizaveta O. Lobova, Post-graduate student, minor researcher, Moscow Technical University of Communications and Informatics, Moscow, Russia Efim A. Liberman, Engineer, Moscow Technical University of Communications and Informatics, Moscow, Russia

Для цитирования:

Лобов Е.М., Припутин В.С., Лобова Е.О., Либерман Е.А. Следящий компенсатор дисперсионных искажений на основе сигма-точечного фильтра Калмана // T-Comm: Телекоммуникации и транспорт. 202I. Том I5. №I. С. 4I-47.

For citation:

Lobov E.M., Priputin V.S., Lobova E.O., Liberman E.A. (202I) Dispersion distortion tracking compensator based on the sigma-point Kalman. T-Comm, vol. 15, no. I, pp. 4I-47. (in Russian) 


\section{Introduction}

In the modern world, the relevance of transmitting broadband information signals in the decameter range has increased $[1,2]$. It is necessary to take into account the effect of the frequency dispersion of the ionosphere, which leads to significant distortions of the useful signal and a decrease in the quality of information reception, in order to receive such information signals. [3-6]. Therefore, estimation of the parameters of the frequency dispersion of the ionospheric channel becomes an important task. The ionospheric channel model is described in [7]. The ionospheric channel model with a linear dependence of the signal group delay on the central frequency of the wave packet was chosen. The considered model is nonlinear with respect to the estimated parameter, which necessitates the use of optimal nonlinear filtering. The article considers the problem of estimating the slope of the dispersion characteristic (DC) of a broadband ionospheric channel $s$ using a Kalman sigma-point filter.

\section{Formulation of the problem}

We can write a system of equations consisting of an equation of a dynamical system and two observation equations as

$$
\left\{\begin{array}{l}
s_{i}=C_{i} s_{i-1}+\xi \\
y_{1 i}=f_{1 i}\left(s_{i}\right)+\mu_{1 i} ; \\
y_{2 i}=f_{2 i}\left(s_{i}\right)+\mu_{2 i},
\end{array}\right.
$$

where $\mu_{1 i}, \mu_{2 i}-$ white Gaussian observation noise; $\xi_{i}-$ noise of the dynamical system; $M\left[\mu_{1 i}\right]=M\left[\mu_{2 i}\right]=0$ is an average noise value of $\mu_{1 i}, \mu_{2 i} ; M\left[\xi_{i}\right]=0$ is an average noise value of $\xi_{i} ; M[\ldots]$ - the average operator; $D\left[\mu_{1 i}\right]=D\left[\mu_{2 i}\right]=\sigma_{\mu}^{2}$ is a noise variance of $\mu_{1 i}, \mu_{2 i} ; D\left[\xi_{i}\right]=\sigma_{\xi}^{2}$ is a noise variance of the dynamic system $\xi_{i}, D[\ldots]$ - a variance operator; $N_{s}$ is a the sample length;

$$
\begin{aligned}
& f_{1 i}\left(s_{i}\right)=\operatorname{Re}\left(\frac{1}{N} \sum_{k=-N_{s} / 2}^{N_{s} / 2-1}\left|\dot{X}_{k}\right|^{2} e^{-j \pi s_{i} f_{k}^{2}}\right) ; \\
& f_{2 i}\left(s_{i}\right)=\operatorname{Im}\left(\frac{1}{N} \sum_{k=-N_{s} / 2}^{N_{s} / 2-1}\left|\dot{X}_{k}\right|^{2} e^{-j \pi s_{i} f_{k}^{2}}\right)
\end{aligned}
$$

$-\mathrm{n}$ nlinear functions of observation equations corresponding to quadratures at the output of the quadrature demodulator and correlator; $\dot{X}_{k}$ - useful signal spectral samples; $s_{i}$ - samples of the estimated random process (the DC slope $S$ ). We can assume that the DC slope $S$ is a slowly varying parameter. The random process $s_{i}$ is estimated using the Kalman sigma-point filter.

\section{The Kalman sigma-point filter}

A special characteristic of the Kalman sigma-point filter is that the a priori estimate of the unknown parameter is calculated as the weighted sum of the sigma-points.
We can calculate the a priori estimate of the slope of the DC $S$ at sigma-points as

$$
\hat{S}_{i}^{-}=\sum_{k=0}^{2 N} \omega^{k} C_{i} S_{i}^{k}
$$

where $S_{i}^{k}$ - sigma-points, which we define as

$$
\left\{\begin{array}{l}
S_{i}^{0}=S_{i-1} \\
S_{i}^{k}=S_{i-1}+\sqrt{N+\lambda}\left(\sqrt{P_{i-1}}\right)^{k}, k=1, \ldots N \\
S_{i}^{k}=S_{i-1}-\sqrt{N+\lambda}\left(\sqrt{P_{i-1}}\right)^{k}, k=N+1, \ldots 2 N
\end{array},\right.
$$

$P_{i}$ is a dynamical system covariance matrix, $\left(\sqrt{P_{i-1}}\right)^{k}$ is the $k$-th matrix column, $\omega^{k}$ - weights used to approximate the mean, $N$ is a dynamic system order.

In the case considered in this article $N=1$, therefore we can rewrite (4) as

$$
\left\{\begin{array}{l}
S_{i}^{0}=S_{i-1} \\
S_{i}^{1}=S_{i-1}+\sqrt{1+\lambda}\left(\sqrt{P_{i-1}}\right) \\
S_{i}^{2}=S_{i-1}-\sqrt{1+\lambda}\left(\sqrt{P_{i-1}}\right)
\end{array}\right.
$$

The estimate of the covariance matrix of the dynamical system has the form

$$
P_{i}^{-}=\sum_{k=0}^{2 N} \omega_{c}^{k}\left(C_{i} S_{i}^{k}-\hat{s}_{i}^{-}\right)\left(C_{i} S_{i}^{k}-\hat{s}_{i}^{-}\right)^{T}+B,
$$

where $B=\sigma_{\xi}^{2}, \omega_{c}^{k}$ - weights used to approximate the covariance matrix.

The calculation of the estimates of the observation equations, which are necessary for the correction of estimates (6) and (3), is made using the following expressions for the mean

$$
\hat{\mathbf{Y}}_{i}=\sum_{k=0}^{2 N} \omega^{k} \mathbf{F}\left(S_{i}^{k}\right)
$$

where $\mathbf{F}\left(S_{i}^{k}\right)=\left[\begin{array}{l}f_{1 i}\left[S_{i}^{k}\right] \\ f_{2 i}\left[S_{i}^{k}\right]\end{array}\right]$

and the covariance matrix

$$
\mathbf{L}_{i}=\sum_{k=0}^{2 N} \omega_{c}^{k}\left(\mathbf{F}\left(S_{i}^{k}\right)-\hat{\mathbf{Y}}_{i}\right)\left(\mathbf{F}\left(S_{i}^{k}\right)-\hat{\mathbf{Y}}_{i}\right)^{T}+\mathbf{Q}
$$

$\mathbf{Q}=M\left[\mu_{i} \mu_{i}^{T}\right]$ is a covariance matrix of an observation equation noise.

The weight coefficients in expressions (3) and (7) are

$$
\omega^{0}=\frac{\lambda}{\lambda+N}, \omega^{k}=\frac{1}{2(\lambda+N)}, k=1, \ldots, 2 N,
$$


in (6) and (8)

$$
\omega_{c}^{0}=\frac{\lambda}{\lambda+N}+1-\alpha^{2}+\beta, \omega_{c}^{\pi}=\frac{1}{2(\lambda+N)}, k=1, \ldots, 2 N .
$$

The expressions for $\omega^{k}$ and $\omega_{c}^{k}$ contain free parameters $\lambda$, $\alpha$ and $\beta$. The parameter $\alpha$ determines the spread of sigma points around the mean, the parameter $\beta$ allows us to take into account a priori data on the probability density function of the estimated parameter, $\lambda$ is the scaling parameter, $\lambda=\alpha^{2}(N+\kappa), \kappa=3-N$.

The final equations for estimating the slope of the DC have the form

$$
\begin{gathered}
\hat{s}_{i}=\hat{s}_{i}^{-}+\mathbf{K}_{i}\left(\mathbf{Y}_{i}-\hat{\mathbf{Y}}_{i}\right), \\
P_{i}=P_{i}^{-}-\mathbf{K}_{i} \mathbf{L}_{i} \mathbf{K}_{i}^{T},
\end{gathered}
$$

$\mathbf{Y}_{i}=\left[\begin{array}{l}y_{1 i} \\ y_{2 i}\end{array}\right]$ is a vector of observation equations, $\hat{s}_{0}$ is chosen from a priori information, $\mathbf{K}_{i}$ is a Kalman filter gain

$$
\begin{aligned}
& \mathbf{K}_{i}=\mathbf{T}_{i} \mathbf{L}_{i}^{-1} \\
& \mathbf{T}_{i}=\sum_{k=0}^{2 N} \omega_{c}^{k}\left(S_{i}^{k}-\hat{s}_{i}^{-}\right)\left(\mathbf{F}\left(S_{i}^{k}\right)-\hat{\mathbf{Y}}_{i}\right)^{T} .
\end{aligned}
$$

As a result, to estimate the slope of the DC, it is necessary to calculate (3), (6) - (12) at three sigma-points (5).

Figure 1 shows the results of the estimation algorithm (9), (10) for different initial true values of the DC slope the under the assumption of a damped process $s\left(C_{i}=0.9995\right) ; s$ is a process with independent random increments $\left(C_{i}=1\right)$ in Figure 2. In simulation, it was assumed that $\sigma_{\xi}=0.01$.
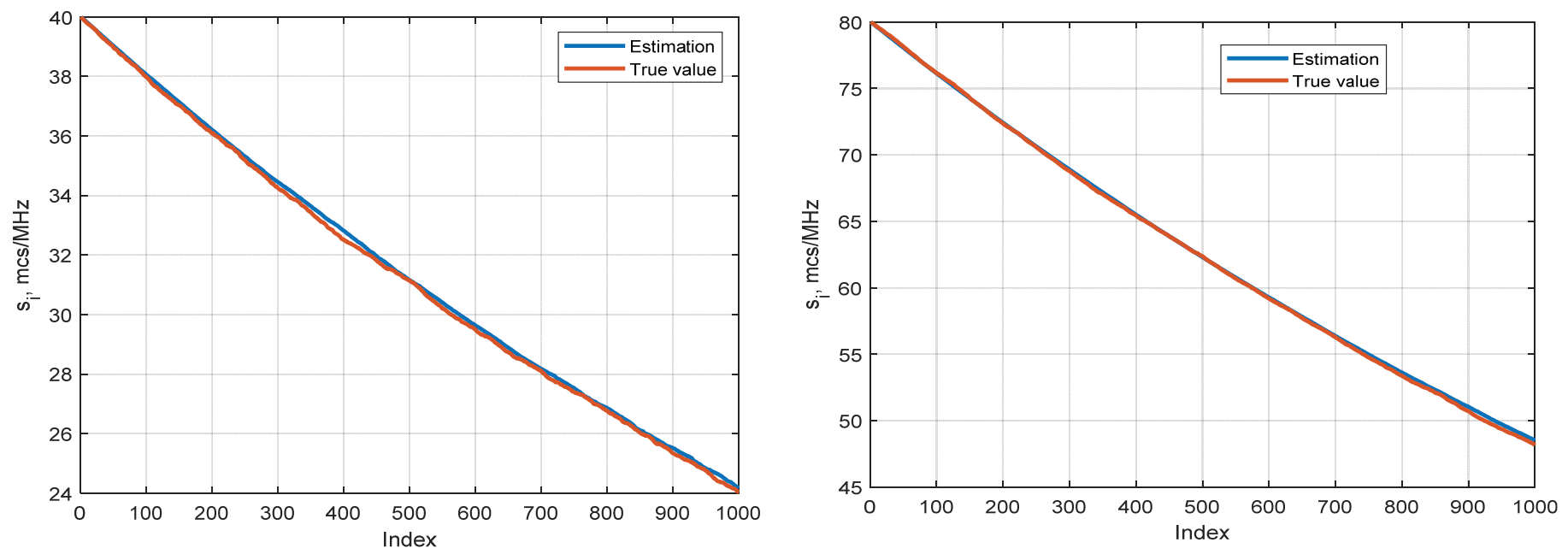

Figure 1. The Estimation and the true value of the DC slope at the initial value $s=40 \mu \mathrm{s} / \mathrm{MHz}$ (on the left) and $s=80 \mu \mathrm{s} / \mathrm{MHz}$ (on the right)
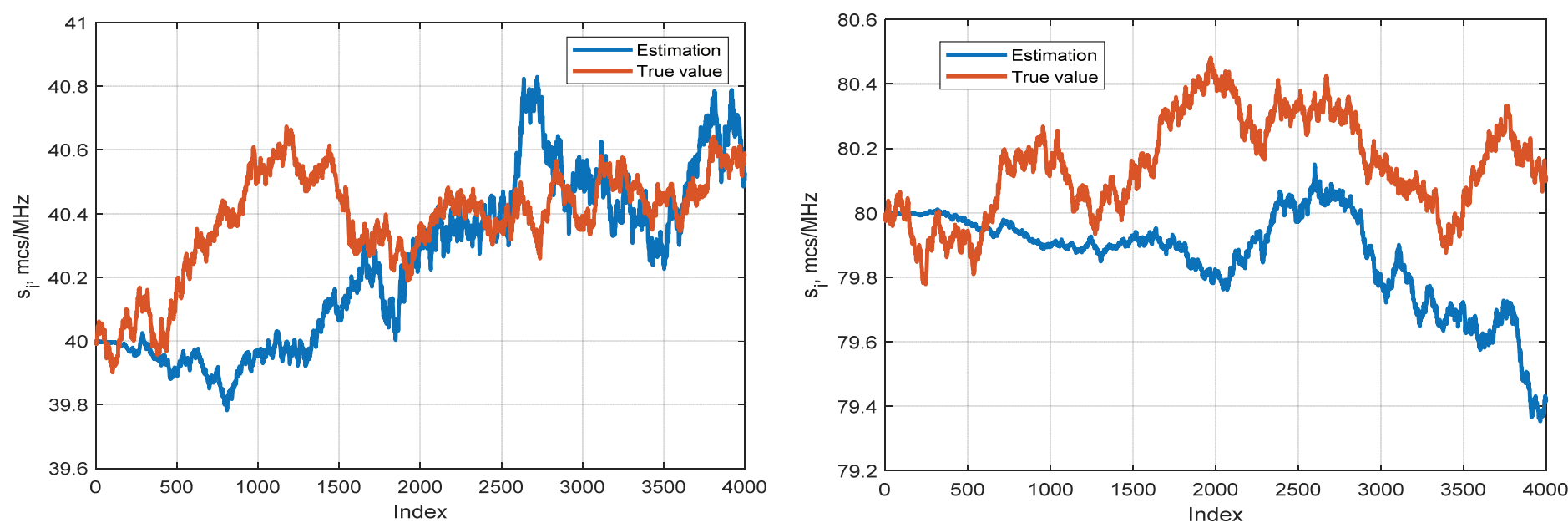

Figure 2. The Estimation and the true value of the DC slope at the initial value $s=40 \mu \mathrm{s} / \mathrm{MHz}$ (on the left) and $s=80 \mu \mathrm{s} / \mathrm{MHz}$ (on the right) 


\section{ELECTRONICS. RADIO ENGINEERING}

A wideband phase-shift keyed signal with a base of 2047 and a $1 \mathrm{MHz}$ bandwidth was used in the simulation. Free parameters were chosen as $\beta=2$ (normal distribution), $\alpha=10$. Such a large value for the parameter $\alpha$ and, as a consequence $\lambda$, was chosen to avoid the influence of the oscillating properties of the components of the matrix $\mathbf{F}$, which lead to the appearance of ambiguity in the filtering algorithm [8].

From a comparison of the obtained dependences (Figure 1), it can be seen that with an increase of the DC slope, the quality of estimation is decreasing; the maximum deviation of the estimate from the true value is $2.5 \mu \mathrm{s} / \mathrm{MHz}$ for $s=80 \mu \mathrm{s} / \mathrm{MHz}$, which is generally acceptable. If $S$ is considered to be almost constant (Figure 2), then the maximum deviation of the estimate from the true value is $1 \mu \mathrm{s} / \mathrm{MHz}$ for $s=80 \mu \mathrm{s} / \mathrm{MHz}$. The quality of the algorithm estimation depends on a priori information about the estimated parameter, which is typical for optimal nonlinear filtering methods.

The Kalman sigma-point filter with compensation of the DC slope

Consider the algorithm for compensating the DC slope. We can rewrite the system of equations (1) with the introduction of the algorithm for compensating the DC slope into the observation equations

$$
\left\{\begin{array}{l}
s_{i}=C_{i} s_{i-1}+\xi_{i} ; \\
y_{1 i}=f_{1 i}\left(s_{i}, \hat{s}_{o i}\right)+\mu_{1 i} ; \\
y_{2 i}=f_{2 i}\left(s_{i}, \hat{s}_{o i}\right)+\mu_{2 i},
\end{array}\right.
$$

$\hat{S}_{o i}$ is an optimal estimation of the DC slope $s$,

$$
\begin{aligned}
& f_{1 i}\left(s_{i}\right)=\operatorname{Re}\left(\sum_{k=-N_{s} / 2}^{N_{s} / 2-1}\left|\dot{X}_{k}\right|^{2} e^{-j \pi f_{k}^{2}\left(s_{i}-\hat{s}_{o i}\right)}\right) ; \\
& f_{2 i}\left(s_{i}\right)=\operatorname{Im}\left(\sum_{k=-N_{s} / 2}^{N_{s} / 2-1}\left|\dot{X}_{k}\right|^{2} e^{-j \pi f_{k}^{2}\left(s_{i}-\hat{s}_{o i}\right)}\right)
\end{aligned}
$$

- nonlinear functions of observation equations which include an estimation of the DC slope $\hat{s}_{o i}=C_{i} \hat{s}_{i-1}, \quad i=\overline{1 \div N}_{s}$, $\hat{s}_{o 1}=C_{1} \hat{s}_{0}$.

This means that after each iteration, each new count of the control action $\hat{S}_{o i}$ is assigned the value calculated at the previous step and predicted for the current step $C_{i} \hat{s}_{i-1}$. The filtering algorithm corresponds to (9) - (12) taking into account (14).
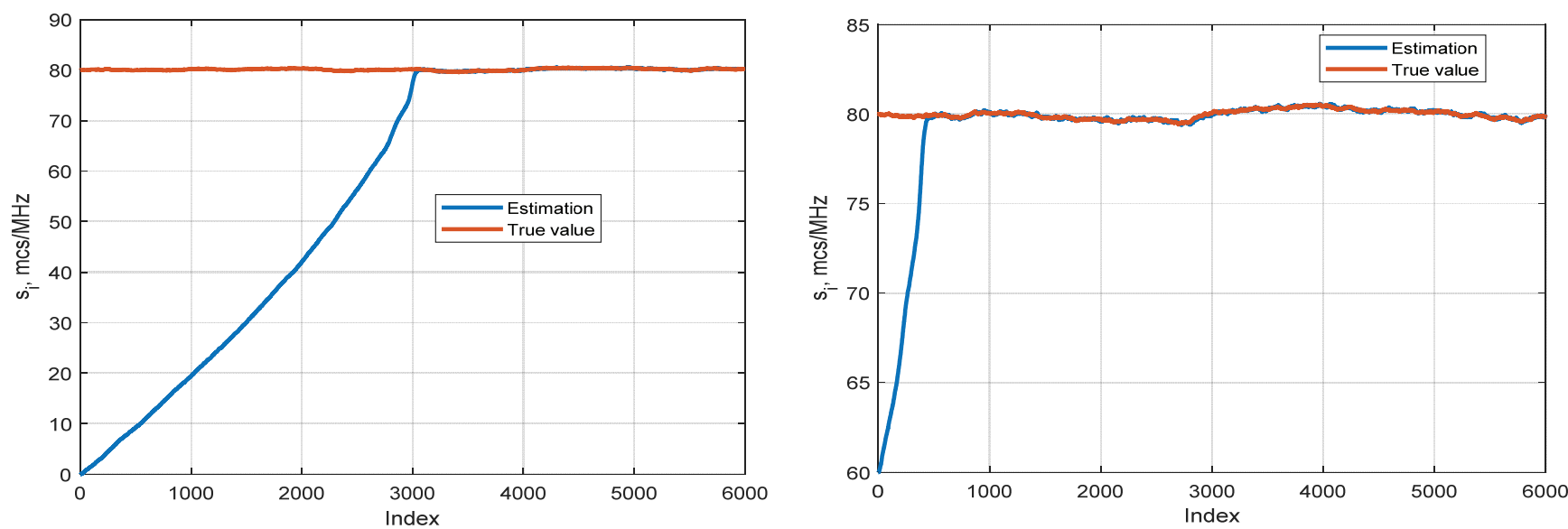

Figure 3. The Estimation and the true value of the DC slope for the initial approximation $s_{0}=0 \mu \mathrm{s} / \mathrm{MHz}$ (on the left) and $s_{0}=60 \mu \mathrm{s} / \mathrm{MHz}$ (on the right)
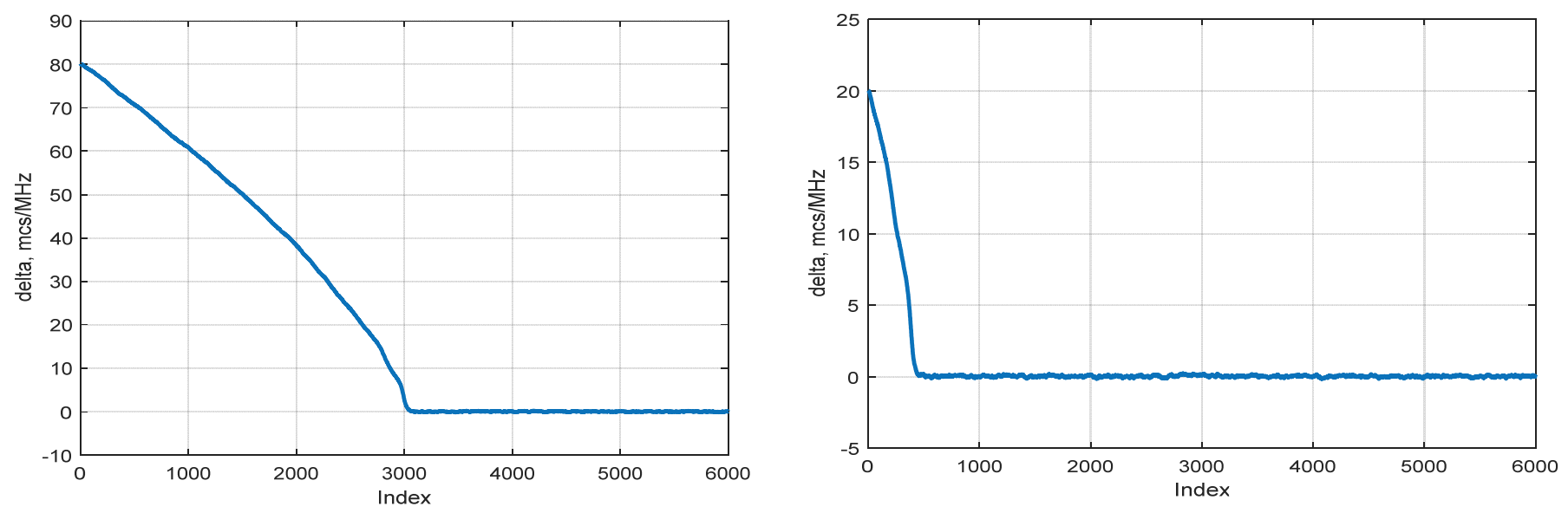

Figure 4. The estimation error of the DC slope at $s=80 \mu \mathrm{s} / \mathrm{MHz}$ for the initial approximation $s_{0}=0 \mu \mathrm{s} / \mathrm{MHz}$ (on the left) and $s_{0}=60 \mu \mathrm{s} / \mathrm{MHz}$ (on the right) 
Figure 3 shows the curves of estimating the parameter $s$ for the algorithm with compensation of dispersion distortions at $s=80 \mu \mathrm{s} / \mathrm{MHz}$ with different a priori information.

Figure 4 shows the estimation error for $s=80 \mu \mathrm{s} / \mathrm{MHz}$, defined as $\Delta=s-\hat{s}_{o i}$.

We can see from the dependencies shown in Figure 3, 4 that the quality of the estimation with compensation has increased, since the compensation of distortions makes it possible to compensate energy losses. The maximum deviation of the estimation from the true value after tuning the algorithm was about 0.1 $\mu \mathrm{s} / \mathrm{MHz}$. The estimation error (Figure 4) at the first stage of estimation is equal to the difference between the true value of the DC slope and the prior information, and then the estimation algorithm gradually adjusts to the true value and $\Delta \rightarrow 0$. Moreover, the algorithm adjusts the faster, the more accurate the a priori information, which once again confirms the strong dependence of the quality of the optimal filter on the prior information.

\section{Computational efficiency of the algorithms}

Figure 5, Figure 6 show schemes for estimating the DC slope using the sigma-point Kalman filter without compensation and with compensation for dispersion distortions, respectively. Block "Calc. $S_{i}^{k}$ "is used for calculating sigma-points, blocks" Calc. $\hat{s}_{i}^{-} "$ and "Calc. $P_{i}^{--}$allow to determine an a priori estimate of the DC slope and the covariance of the dynamic system, respectively," Calc. $\mathbf{F}\left(S_{i}^{k}\right)$ " calculates the observation equations according to (2) (Figure 5 or (14) (Figure 6),"Calc. $\hat{\mathbf{Y}}_{i}$ " and " Calc. $\mathbf{L}_{i}$ " calculate the estimates of the mean and covariance matrix of the observation equations, block" Calc. $\mathbf{T}_{i}$ " calculates the estimation of the cross-correlation between the estimated parameter and the input signal, block" Calc. $\mathbf{K}_{i}{ }^{\text {" calculates the }}$ Kalman filter gain, " Cor." is a correlator which receives the samples of the input signal $x_{i}$ and the reference signal $x_{i}^{*}$ (also, " Cor." receives the estimation $\hat{s}_{i}$ for the scheme with compensation), blocks "Calc. $\hat{s}_{i}$ " and" Calc. $P_{i}$ " calculate the estimation of the DC slope and the covariance of the dynamic system.

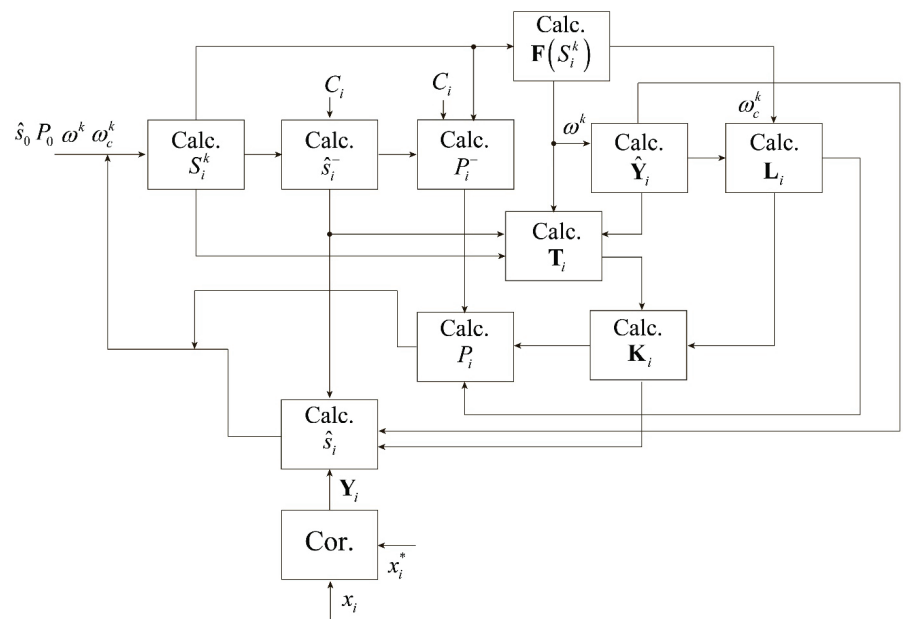

Figure 5. Functional scheme for estimating the DC slope by the Kalman sigma-point filter

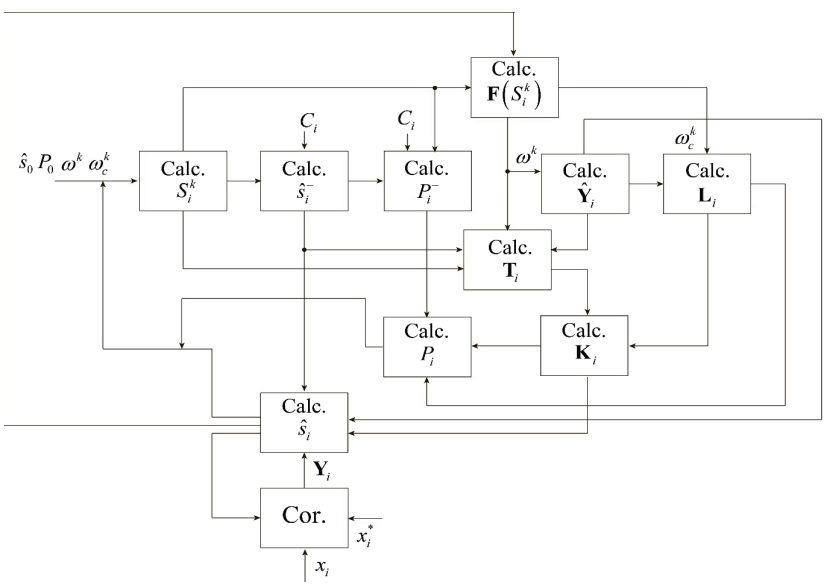

Figure 6. Functional scheme for estimating the DC slope by the Kalman sigma-point filter with compensation

The Table 1 shows equations for the number of computational operations in one sampling period for schemes for estimating the DC slope.

Table 1

Number of computing operations

\begin{tabular}{|c|c|c|}
\hline $\begin{array}{c}\text { The common number of } \\
\text { real operations of multi- } \\
\text { plication and addition }\end{array}$ & $100+23 N_{s}$ & $100+43 N_{s}$ \\
\hline $\begin{array}{c}\text { The number of calcula- } \\
\text { tions of "complex" } \\
\text { mathematical operations }\end{array}$ & $\begin{array}{c}2 \text { operations for cal- } \\
\text { culating square root, } \\
4 \text { operations for divi- } \\
\text { sion, } 3 N_{s} \text { operations } \\
\text { for calculating co- } \\
\text { sine, } 3 N_{s} \text { operations } \\
\text { for calculating sine }\end{array}$ & $\begin{array}{c}2 \text { operations for calcu- } \\
\text { lating square root, } \\
4 \text { operations for divi- } \\
\text { sion, } 3 N_{s} \text { operations } \\
\text { for calculating cosine, } \\
3 N_{s} \text { operations for } \\
\text { calculating sine }\end{array}$ \\
\hline
\end{tabular}

Figure 7 shows the number of real operations of multiplication and addition and the number of "complex" mathematical operations on the sample length. We can see that:

1. The number of computational operations rises with increasing $N_{s}$;

2. The solution with the compensation of the DC slope $S$ requires 1.9 times more real operations of multiplication and addition and 1.3 times more calculations of "complex" mathematical operations.

The solution with the compensation of the DC slope requires 1.9 times more real operations of multiplication and addition and 1.3 times more calculations of "complex" mathematical operations. Note also that the most computationally expensive block in the Kalman nonlinear filtering schemes for the DC slope is the "Calc. $\mathbf{F}\left(S_{i}^{k}\right)$ " (see Figure 5, Figure 6), which calculates the values of functions (2) and (14) at sigma points (5). The number of real operations of multiplication and addition in one sampling period is $15 N_{s}-6 \mathrm{~s}$, operations for calculating "cosine" $-3 N_{s}$ and $3 N_{s}$ operations for calculating "sine" for estimation without compensation. In addition, the number of real operations of multiplication and addition in one sampling period is $27 N_{s}-6 \mathrm{~s}$, operations for calculating the "cosine" $-3 N_{s}$ and $3 N_{s}$ operations for calculating the "sine" for estimation with compensation. 


\section{ELECTRONICS. RADIO ENGINEERING}
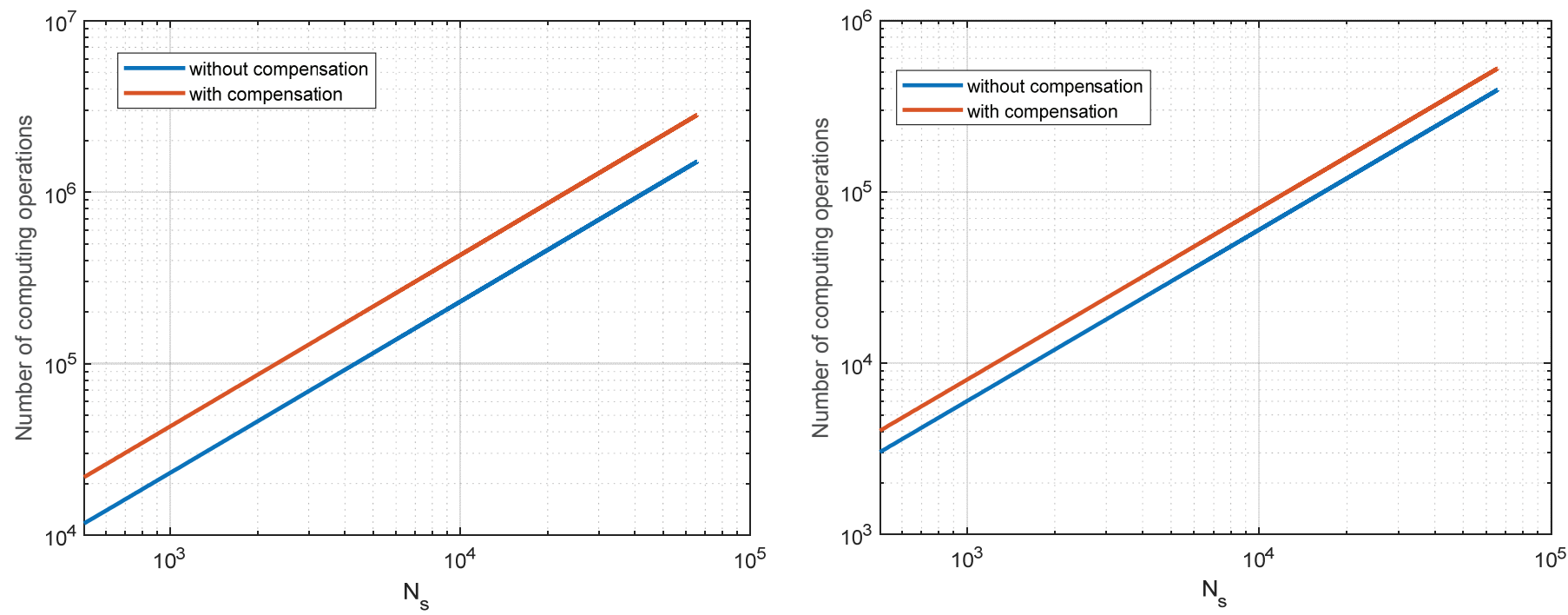

Figure 7. Dependence of the number of real operations of multiplication and addition (on the left) and the number of "complex" mathematical operations (on the right) on the sample length

Nowadays, GPUs are increasingly used to solve DSP problems in real time due to the ability to parallelize computations, support floating-point calculations and hardware support for calculating "complex" mathematical functions. In particular, an analysis of the computational complexity of the algorithm shows that it can be successfully implemented on a six-core ARM RK3399pro processor with a Mali-T860 MP4 GPU with a performance of up to 288 TFLOPS.

\section{Conclusion}

The algorithm for estimating the DC slope using the Kalman sigma-point filter allows to have deviations of the estimated parameter from its true value are no more than about $2.5 \mu \mathrm{s} / \mathrm{MHz}$ for a damped process $s$ and about $1 \mu \mathrm{s} / \mathrm{MHz}$ if $s$ is a process with independent random increments at input SNR of about $20 \mathrm{~dB}$. The quality of the estimation can be improved by correcting dispersion distortions simultaneously with the estimation. The maximum deviation of the estimate from the true value after tuning the algorithm was about $0.1 \mu \mathrm{s} / \mathrm{MHz}$. The obtained algorithm is general and can be applied when using various wideband signals.

\section{Acknowledgments}

The reported study was funded by RFBR, project number 19-29-06055.

\section{References}

1. MIL-STD-188-110C. Military standard - interoperability and performance standards for data modems. US Department of Defense, 3 January 2012.

2. Jorgenson M.B., Johnson R.W., Nelson R.W. An Extension of Wideband HF Capabilities. IEEE Military Communications Conference. 2013. P. 1202-1206.

3. Lobov E.M., Kosilov I.S. Broadband ionospheric radio lines using noise-like signals noise immunity calculation based on prediction data. T-Comm. 2011. Vol. 5. No.11. P. 68-70.

4. Lobov E.M., Smerdova E.O. The dispersion characteristic slope of the ionospheric channel maximum-likelihood estimate quality obtained with probe signals. Telecommunications and information technologies. 2016. Vol. 3. No.2. P. 61-62.

5. Lobov E.M., Smerdova E.O. The dispersion characteristics slope of the ionospheric channel the quality algorithms investigation. Telecommunications. 2017. No.6. P. 28-31.

6. Lobov E.M., Smerdova E.O., Kandaurov N.A. et al. Optimum estimation and filtering of the ionospheric channel dispersion characteristics slope algorithms. Systems of signal synchronization, generationg and processing in telecommunications (SINKHROINFO), 2017 (DOI: 10.1109/SINKHROINFO.2017.7997537).

7. Ivanov D.V. Methods and mathematical models for studying the propagation of complex decameter signals and correcting their dispersion distortions. Yoshkar-Ola: MarSTU, 2006. 266 p.

8. Lobov E.M., Lobova E.O., Kandaurov N.A. Wideband signals dispersion distortion ptimal tracking compensator. Telecommunications. 2018. No.5. P. 34-38. 


\section{СЛЕДЯЩИЙ КОМПЕНСАТОР ДИСПЕРСИОННЫХ ИСКАЖЕНИЙ НА ОСНОВЕ СИГМА-ТОЧЕЧНОГО ФИЛЬТРА КАЛМАНА}

Лобов Евгений Михайлович, Московский технический университет связи и информатики, Москва, Россия, lobov@srd.mtuci.ru

Припутин Владимир Сергеевич, Московский технический университет связи и информатики, Москва, Россия, v.s.priputin@mtuci.ru

Лобова Елизавета Олеговна, Московский технический университет связи и информатики, Москва, Россия, lizabeth2@mail.ru

Либерман Ефим Александрович, Московский технический университет связи и информатики, Москва, Россия

Исследование выполнено при финансовой поддержке РФФИ в рамках научного проекта № 19-29-06055

\section{Аннотация}

В статье предложен алгоритм нелинейной оптимальной фильтрации наклона дисперсионной характеристики ионосферного канала (наклон ДХ) на основе сигма-точечного фильтра Калмана при зондировании канала широкополосными сигналами. Актуальность прилагаемого алгоритма, можно объяснить тем, что в настоящее время в современном мире возросла актуальность передачи широкополосных информационных сигналов в декаметровом диапазоне. Приём таких сигналов усложняется эффектами, вызванными влиянием частотной дисперсии ионосферного канала на сигнал. Вышеупомянутое влияние приводит к существенным искажениям полезного сигнала и снижению качества приема информации в целом. Следовательно, пренебречь влиянием частотной дисперсии нельзя и её необходимо учитывать при разработке алгоритмов оптимального приема. Таким образом, актуальной задачей становится оценка параметров частотной дисперсии ионосферного канала. Приведены рекуррентные формулы для расчета оптимальной фильтрации наклона ДХ. Более того, представлен алгоритм совместной оценки дисперсионных искажений и их компенсации, позволяющий улучшить качество оценивания. Приведены результаты имитационного моделирования алгоритмов: полученная оценка и истинное значение параметров частотной дисперсии для двух случаев - марковского затухающего процесса и процесса со случайными приращениями. Также рассмотрена абсолютная ошибка оценки наклона ДХ. Рассчитана вычислительная эффективность работы алгоритма оценки наклона ДХ с помощью сигма-точечного фильтра Калмана с компенсацией и без компенсации. Кроме того, приведены функциональные схемы оптимальной фильтрации наклона ДХ с компенсацией и без неё. Рассмотрены пути реализации предложенного алгоритма на ARM процессоре.

Ключевые слова: частотная дисперсия, широкополосный сигнал, искажения, нелинейная оптимальная фильтрация, сигма-точечный фильтр Калмана, ионосферный канал, ARM

\section{Литература}

I. MIL-STD-I88-I IOC. Military standard - interoperability and performance standards for data modems. US Department of Defense,

3 January 2012.

2. Jorgenson M.B., Johnson R.W., Nelson R.W. An Extension of Wideband HF Capabilities // IEEE Military Communications Conference. 2013. P. I202-I 206.

3. Лобов Е.М., Косилов И.С. Расчет помехоустойчивости широкополосных ионосферных радиолиний с применением шумоподобных сигналов на основе данных прогнозирования // Т-Соmm: Телекоммуникации и транспорт. 20ІІ. Т. 5, № II. C. $68-70$.

4. Лобов Е.М., Смердова Е.О. Качество максимально правдоподобной оценки наклона дисперсионной характеристики ионосферного канала широкополосными сигналами // Телекоммуникации и информационные технологии. 2016. Т. 3, № 2. C. 61-62.

5. Лобов Е.М., Смердова Е.О. Исследование качества алгоритмов оценки наклона дисперсионной характеристики ионосферного канала // Электросвязь. 20I7. № 6. С. 28-3І.

6. Lobov E.M., Smerdova E.O., Kandaurov N.A. et al. Optimum estimation and filtering of the ionospheric channel dispersion characteristics slope algorithms // Systems of signal synchronization, generationg and processing in telecommunications (SINKHROINFO), 20I7 (DOI: 10.1 I09/SINKHROINFO.2017.7997537)

7. Иванов Д.В. Методы и математические модели исследования распространения сложных декаметровых сигналов и коррекции их дисперсионных искажений. Йошкар-Ола: МарГТУ, 2006. 266 с.

8. Лобов Е.М., Лобова Е.О., Кандауров Н.А. Оптимальный следящий компенсатор дисперсионных искажений широкополосных сигналов // Электросвязь. 2018. №5. С. 34-38.

Информация об авторах:

Лобов Евгений Михайлович, зав. лаб., к.т.н., доцент, Московский технический университет связи и информатики, Москва, Россия Припутин Владимир Сергеевич, зав. лаб., к.т.н., доцент, Московский технический университет связи и информатики, Москва, Россия Лобова Елизавета Олеговна, аспирант, м.н.с., Московский технический университет связи и информатики, Москва, Россия

Либерман Ефим Александрович, инженер, Московский технический университет связи и информатики, Москва, Россия 